Review

\title{
Two-Photon Excitation of Azobenzene Photoswitches for Synthetic Optogenetics
}

\author{
Shai Kellner and Shai Berlin *(1) \\ Department of Neuroscience, Ruth and Bruce Rappaport Faculty of Medicine, Technion-Israel Institute of \\ Technology, Haifa 3525433, Israel; shaikellner@gmail.com \\ * Correspondence: shai.berlin@technion.ac.il
}

Received: 1 December 2019; Accepted: 20 January 2020; Published: 23 January 2020

\begin{abstract}
Synthetic optogenetics is an emerging optical technique that enables users to photocontrol molecules, proteins, and cells in vitro and in vivo. This is achieved by use of synthetic chromophores-denoted photoswitches - that undergo light-dependent changes (e.g., isomerization), which are meticulously designed to interact with unique cellular targets, notably proteins. Following light illumination, the changes adopted by photoswitches are harnessed to affect the function of nearby proteins. In most instances, photoswitches absorb visible light, wavelengths of poor tissue penetration, and excessive scatter. These shortcomings impede their use in vivo. To overcome these challenges, photoswitches of red-shifted absorbance have been developed. Notably, this shift in absorbance also increases their compatibility with two-photon excitation (2PE) methods. Here, we provide an overview of recent efforts devoted towards optimizing azobenzene-based photoswitches for 2PE and their current applications.
\end{abstract}

Keywords: two-photon; azobenzene; optogenetics; photoswitch

\section{Introduction}

Photoreceptors are protein light-detectors that allow the cell/organism to respond to its environment [1]. Most, if not all, photoreceptors are a two-component system: a genetically-encoded protein coupled to a chromophore. Following photon-absorption, chromophores undergo unique alterations (for instance in geometry or charge [2,3]), resulting in the modulation of the protein partner to which each chromophore is bound to. In most instances, this process is completely reversible, whereby removal of light (i.e., return to darkness) facilitates the relaxation of the chromophore to its initial, thermally stable state. This also restores the function of the protein back to as it were prior illumination. These features, explicitly non-invasive reversible control over proteins, have made it possible to develop fantastic genetically-encoded optical tools-denoted 'optogenetic' tools-for the manipulation of defined subsets of cells [4]. Many tools today are based on naturally-occurring photoreceptors, for instance opsins [5-8]. However, the need to photocontrol other signaling mechanisms, proteins or molecules, have pushed forward the development of complementary strategies, explicitly Synthetic optogenetics $[9,10]$.

Synthetic optogenetics relies on the use of non-natural, synthetic chromophoresphotoswitches-to relay photon absorption to modulation of structure and function of their target molecule (Figure 1a). Photoswitches do not require a unique chromophore binding pocket or protein domains as in the case of chromophores (e.g., [11]). Instead, photoswitches can be directly conjugated to various locations on their target molecule with use of different genetic or chemical handles (see below) $[9,12]$. However, unlike chromophores that can be synthesized by various cells (even if the cells are not intrinsically light-sensitive), photoswitches need to be supplemented to the preparation. This is both a blessing and a curse. Blessing—since the preparation remains naïve until the photoswitch 
is added. Curse-it adds another layer of complexity to the experiment, especially in vivo, such as injection prior experimentation.

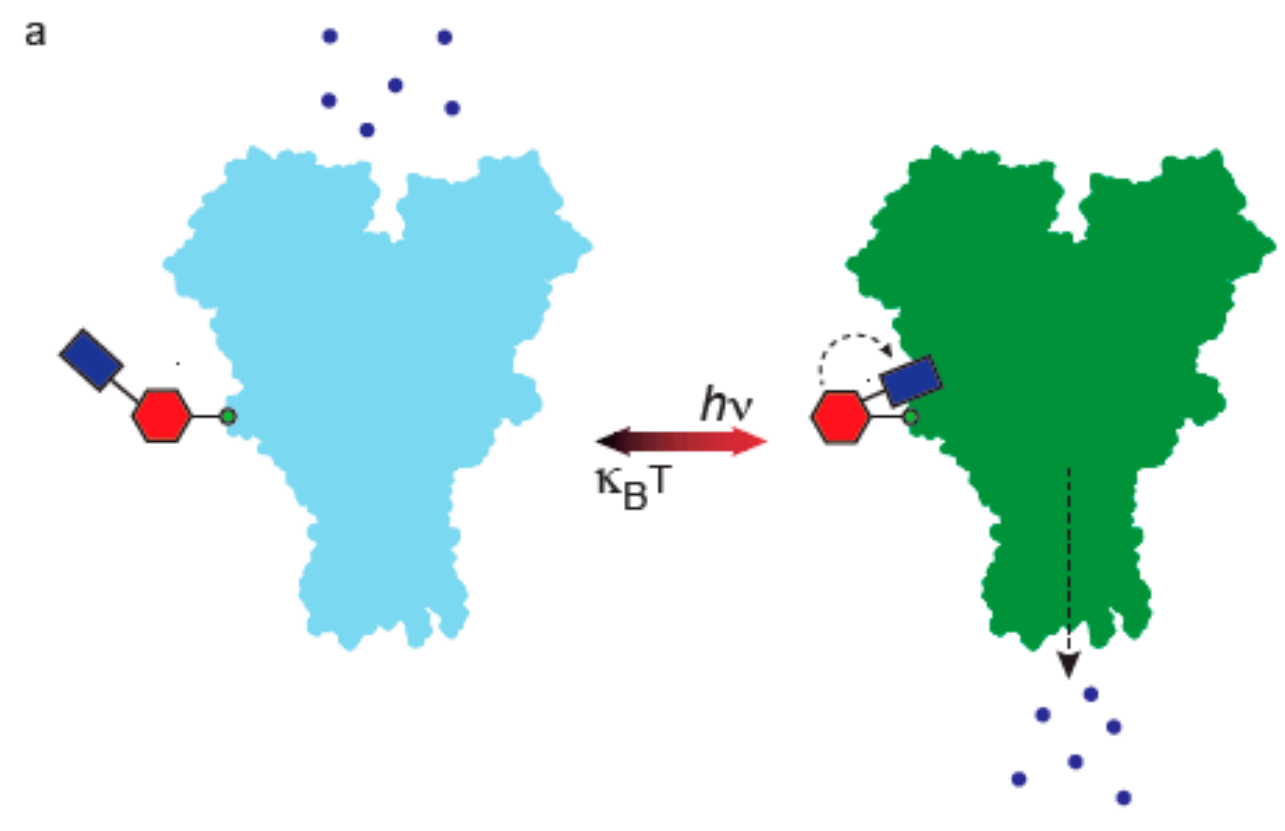

b

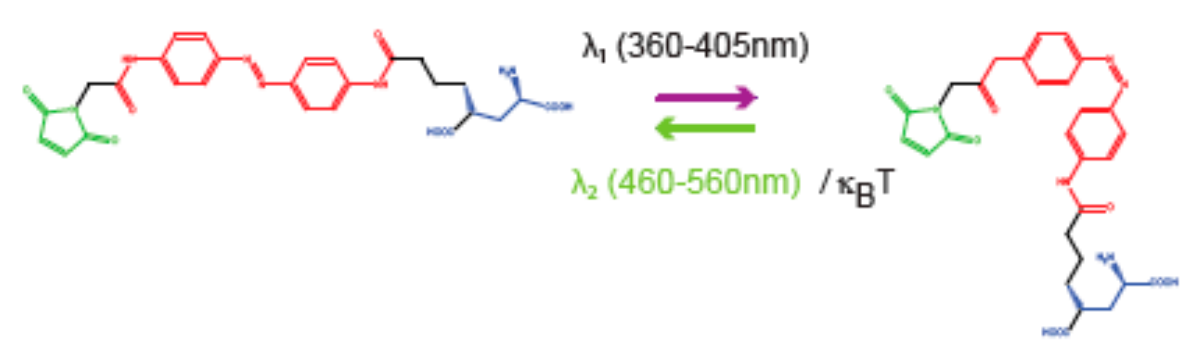

Figure 1. Synthetic optogenetics. (a) Cartoon depiction of a photoswitchable glutamate receptor (space filling based on PDB: 3KG2). For simplicity, only two of four subunits are presented. In addition, only one subunit is shown to tether the photoswitch (color-coded shapes). The photoswitch consists of a ligand (purple rectangle), an azobenzene-core (red hexagon) and a maleimide for attachment (green circle). In the dark, the photoswitch is in -trans and channel is closed (leftward cartoon, light blue). Photoisomerization of the photoswitch to -cis by red-shifted light $(h v)$ allows insertion of the glutamate headgroup (purple rectangle) into its binding pocket inducing channel opening (rightward cartoon, green receptor; dashed arrow depicts conductance of ions). (b) Chemical structure of an exemplary photoswitch; MAG (color coded as in (a); maleimide-green; azobenzene-red; glutamate-purple). Visible light photoisomerization (common to most photoswitches): $360-405 \mathrm{~nm}$ light photoisomerizes MAG from -trans to -cis; illumination at $\sim 460-560 \mathrm{~nm}$ (or thermal relaxation; $\mathrm{K}_{\mathrm{B}}^{\mathrm{T}}$ ) returns MAG to -trans.

Photoswitches can be custom-tailored to photomodulate a large variety of effectors. For instance, some have been fashioned to mechanically restructure membrane lipids or DNA molecules [13-15], to act as light-activated forceps [16] or to include pharmacological agents (e.g., pore-blockers) to block, agonize, or antagonize receptors, ion channels, or enzymes (Figure 1b) (also see reviews $[9,17,18]$ ). It is noteworthy to mention that although this method dates back to the late 1960s (Figure 2) [19], it has particularly gained momentum in early 2000 owing to critical advances in chemistry, biology, and imaging methods. Here, we focus on the most recent efforts devoted to push it to the next level, namely towards multiphoton activation of photoswitches for in vivo applications in opaque preparations. 
Owing to the versatility of the technique, we foresee a bright future for 2PE-compatible photoswitches in biology and medicine.

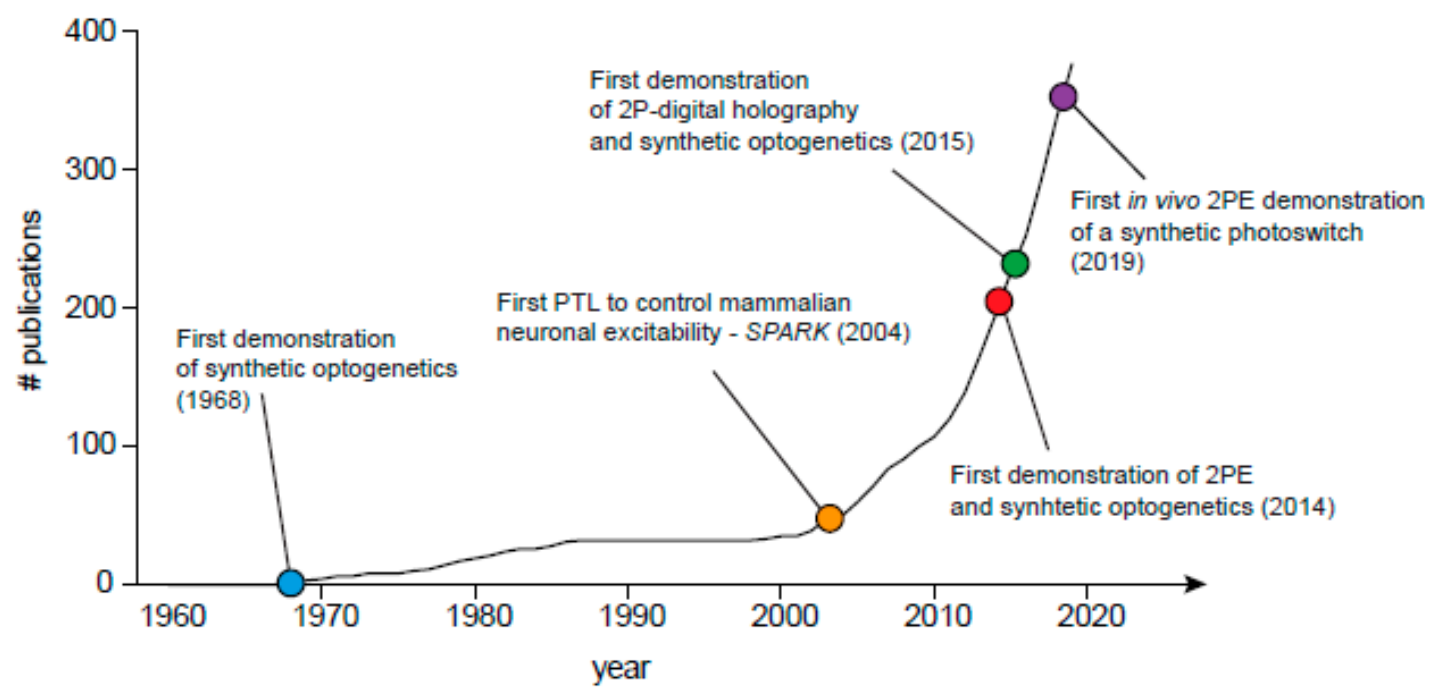

Figure 2. Graphical illustration of 'synthetic optogenetics' emerging in the scientific literature. Cumulative plot of number of publications across years was performed by searching for specific terms (chemical-optogenetics, photopharmacology, optopharmacology, synthetic optogenetics, optogenetic pharmacology, photoswitch, azobenzene and photo), as well as by searching for publications from recognized researchers in the field (e.g., Erlanger BF, Poolman B, Feringa B, Lester HA, Trauner D, Kramer RH, Isacoff EY, Woolley GA, Gorostiza P, Paoletti P, Ellis-Davies GCR, etc.). Search was continuously performed in various search engines, notably PubMed Central, Google Scholar, and bioRxiv. Last query was performed on November 2019.

\section{Photoswitches}

At the heart of photoswitches lies a light-sensitive core [20]. Of the different kinds, the most prevalent moiety used in biological applications is the azobenzene (Figure 1b) [21]. Its widespread use arises from favorable features, such as high quantum yield, minimal photobleaching, and fast responsivity at biologically-relevant conditions, namely $\mathrm{pH}$, temperature and solubility in water-based solvents [21-23]. However, its ability to undergo trans-to-cis photoisomerization is undoubtfully the main reason; giving rise to robust changes in geometry and end-to-end distance of the molecule (Figure 1b).

Azobenzene photoswitches commonly include additional chemical groups placed on either side of the light-sensitive core. These can be quite diverse, such as drugs, chemical- or biological tethers, dyes, as well as lipidic structures [9]. The nature of these groups will dictate the mode of action of the photoswitch and whether it is to remain diffusive or immobilized to its target. Diffusive photoswitches (photochromic ligands; PCL) are, in principle, reversible caged-compounds [24]. In contrast, immobilized photoswitches (photoswitchable tethered ligand; PTL [25]) include a unique chemical tether that can conjugate specific residues of the protein (e.g., maleimide to bind cysteines [26]; benzylguanine to a SNAP domain [27]). These restrict the binding (thereby the effect) of the photoswitch to a defined molecule. Importantly, specific amino acids (a.a.) or domains can be genetically-encoded, thereby giving users access to defined populations of cells. Today, most targets for PTLs require genetic modifications, with cysteines as the preferred choice. However, recent advances have made it possible to conjugate photoswitches to endogenous, non-modified receptors by use of strong electrophilic moiety in the PTL to couple with reactive amines and hydroxyl groups, naturally present in several a.a. side chains [28]. Another scheme to bypass protein modification is by attaching the photoswitch next to its intended target. This may include expression of membrane anchors (e.g., a transmembrane 
domain with the tether facing the extracellular) to conjugate the photoswitch which can then modulate adjacent endogenous proteins [29].

\section{Photomodulating Cellular Activity}

One prototypical example of a synthetic optogenetic tool is SPARK (Synthetic Photoisomerizable Azobenzene-Regulated $\mathrm{K}^{+}$-channel) [30]. SPARK was designed to control neuronal excitability. This channel was designed to tether MAL-AZO-QA. MAL-AZO-QA includes an azobenzene (AZO) flanked by a cysteine-reactive maleimide (MAL) and a potassium channel blocker (quaternary ammonium; QA). For the maleimide to specifically tether SPARK, the channel had a cysteine residue inserted in one of its external loops (as water-accessible cysteines are not common in proteins [31]). Prior illumination, the photoswitch is found in its elongated -trans form; spanning $17 \AA$. The authors designed the length of the photoswitch to equal the distance between the cysteine residue and the pore so that the QA drug would easily reach the pore and block the channel. The functional outcome of blocking this potassium channel is robust neuronal excitability and action potential firing. This effect was completely reversed by near-UV illumination $(\sim 400 \mathrm{~nm})$, pushing the photoswitch back to -cis, a much shorter form (end-to-end distance $\sim 10 \AA$ ), thereby physically removing the blocker away from the pore leading to immediate silencing of the neuron [30]. This could be repeated many times, by quickly toggling the photoswitch back to -trans by $\sim 500 \mathrm{~nm}$ light (rather than slow thermal relaxation in the dark). Similar schemes have been adopted to photocontrol a variety of channels and receptors with the, almost exclusive, use of visible light $[9,12]$.

\section{Shifting from Visible to Near-Infrared}

Despite progresses made since the very first demonstrations of Synthetic optogenetics by the Erlanger group in the late 1960s [19,32], current illumination schemes remain as they were back then, namely rely on the use of visible light, typically near-UV $(\sim 400 \mathrm{~nm})$ for trans-to-cis photoisomerization and blue-shifted wavelengths $(\sim 500)$ for cis-to-trans $[9,12,15,17,18,24,33,34]$. Aside the potential cytotoxicity of these wavelengths $[35,36]$, visible light is not well-suited for deep tissue penetration due to strong absorption and scatter from endogenous components [37]. The use of longer, near infrared $(\mathrm{NIR} ;>700 \mathrm{~nm}$ ) wavelengths is advantageous as these are less absorbed by biological tissues and water [38], induce less photodamage [36], and are less prone to scatter.

Synthetic optogenetics is slow to adapt NIR illumination owing to the very poor absorbance of these low energy wavelengths by the azobenzene core, a common challenge with other optogenetic tools [39], not to mention the relatively little information extant for NIR absorption by photoswitches $([40,41]$ and see below). In fact, though the -cis azobenzene was first discovered almost a century ago (see [42]), the debate regarding the exact mechanism for photoisomerization, and how different factors affect it, remains lively to this day $[43,44]$. Following excitation, the azobenzene molecule proceeds from S0 to S1 and S2 states, with distinct absorption bands for each transition (n- $\pi^{*}$ transition excite azobenzene compounds to S1 state and $\pi-\pi^{*}$ transition leads to S2 state) $[45,46]$. However, many different factors can have dramatic influences on the these, for instance substitutions on the phenyl rings, solvent properties, temperature, to name the more common factors. However, it is much less known by which of the proposed mechanisms the isomerization of azobenzene proceeds, namely rotation, inversion, concerted inversion, and inversion assisted rotation (for more details see [44]). These uncertainties arise from different approaches used, or different experimental settings. For instance, whereas non-viscous polar solvents favor a rotation mechanism, viscous non-polar favor inversion [44]. It has also been shown that the use of different wavelengths can affect the isomerization mechanism. In fact, these differences are also seen with other compounds such as fluorescent proteins $[47,48]$ and extant data of how wavelengths affect isomerization mostly pertains to one-photon excitation of azobenzene compounds [49]. This actuality makes it very difficult to infer the mechanisms for NIR excitation as the absorption properties between these different illumination schemes are substantially different [41]. For instance, use of 1-photon for isomerization shows that 
the transition from trans-to-cis path develops triexponentially with times of $0.3,3$, and 16 ps (where the first two reflect population relaxation and the third corresponds to the final relaxation to ground state [49]) and these are not affected by solvent viscosity rather by wavelengths at early ( $t \sim 1 \mathrm{ps}$ ) and late ( $t \sim 100 \mathrm{ps}$ ) times but show similar photoisomerization behavior on a $10 \mathrm{ps}$ time scale [50].

Some of these hurdles can be overcome by using, at least, two NIR photons; each with half the energy of needed, to be absorbed in a single event (within $\sim 10^{-18} \mathrm{~s}$ ) in order to reach the molecule's excited state [51]. For instance, if a photoswitch/chromophore efficiently absorbs near-UV light at 400 $\mathrm{nm}$, in principle it should be possible to excite it by two simultaneous photons at approximately $800 \mathrm{~nm}$ each [41]. This technique is denoted two-photon excitation (2PE) [52]. However, it is important to note that $2 \mathrm{PE}$ is a third-order nonlinear process that depends not only on the absorption cross-section $(\sigma 2)$ of the molecule, but also on the concentration of incident photons. Therefore, even small differences in laser conditions can lead to very different absorptions; making it difficult to compare compounds, or even the relative strength of transitions. Nevertheless, recent reports addressing these issues show that the fundamental excitation of the $\mathrm{S} 0 \rightarrow \mathrm{S} 2$ transition by $2 \mathrm{P}$ are similar and are due to resonance absorption [50].

2PE allows to excite molecules found deeper within the tissue (up to $\mathrm{mm}$ ), at high three-dimensional, sub-micrometric spatial resolution [51,53]. This provides exquisite means to activate optogenetic tools at the level of single cells, or even subcellular regions, with minimal light escaping to undesired or nearby regions [54]. However, many optical tools display low 2PE absorption cross-section. This is worsened by low expression of the protein under control or its low conductance (in the case of an ion channel) $[55,56]$. Together, these limitations largely render 2PE unusable in these instances. Improving $2 \mathrm{PE}$ could be obtained by increasing the $2 \mathrm{PE}$ cross-section absorption of a photoswitch by chemical modification (s) (see below), by increasing the expression and of the protein or to simultaneously illuminate larger regions-of-interest (ROIs) such as entire somata. Expansion of the illumination area can be obtained by parallel excitation techniques that provide a high flux of photons to numerous ROIs simultaneously, in contrast to rastering methods (line scanning) that provide photons to single pixels sequentially [55,57]. A collection of these improvements have been employed for 2P-photolysis of caged-compounds as well as photoactivation of various opsins for quite some time now [56,58-62] and, only recently, in synthetic optogenetics (Figure 2).

\section{Two-Photon Compatible MAG-Based Photoswitches}

One of the most commonly employed tethered photoswitch is MAG [9] (Figures $1 \mathrm{~b}$ and 2). MAG, similar to MAL-AZO-QA (see above), has an azobenzene-core (A), flanked by a cysteine-reactive maleimide (M), but instead of a channel blocker bears a glutamate molecule $(\mathrm{G})$. This photoswitch is therefore intended for glutamate-binding proteins. The MAG photoswitch has been employed to activate glutamate receptors (e.g., LiGluR, LiGluN, mGluRs) in its -cis form, not to mention to antagonize a glycine-binding receptor (the GluN1a-subunit [26]). Akin to other azobenzene-based photoswitches, MAG undergoes very efficient -trans to -cis photoisomerization when irradiated with near-UV light $\left(\mathrm{MAG}_{0} ; \lambda_{\text {trans-cis }} 340-400 \mathrm{~nm}\right)$, and reverts from -cis back to -trans by thermal relaxation or, significantly more rapidly, by blue-green wavelengths $\left(\mathrm{MAG}_{0} ; \lambda_{\text {cis-trans }} 440-580 \mathrm{~nm}\right)$. Nevertheless, with regards to 2PE, MAG exhibits very poor absorption in the red-to-NIR range $(\sim 700-1400 \mathrm{~nm})$ [41].

In the case of first generation MAGs (MAG0 [26,63,64]), endowed with a symmetrically-substituted azobenzene (Figure 2 and Table 1), the 2P-absorption cross section is low ( $\sigma 2=10 \mathrm{GM}$ at $820 \mathrm{~nm}$ [41]), albeit on the order of magnitude of a common fluorescent protein such as eGFP $(\sigma 2=30 \mathrm{GM}$ at 927 $\mathrm{nm}$ [47]). This, along the lower expression and density of channels at membrane of neurons, results in very little or no capacity to photocontrol cellular activity when 2PE is employed [41]. This prompted the design of second-generation MAGs with increased 2P-absorption cross sections. More precisely, this required lowering the energetic barrier of trans-to-cis isomerization by specifically adjusting and shifting MAG's spectral properties towards 'red'-er wavelengths. 
Table 1. Applications of $2 \mathrm{PE}$ for synthetic optogenetics.

\begin{tabular}{|c|c|c|c|c|c|c|c|}
\hline Photoswitch & Type & $\begin{array}{r}\text { 1P and 2P Peak } \\
\text { Absorption (nm) }\end{array}$ & $\begin{array}{l}\text { 2P-Absorption } \\
\text { Cross-Section (GM) }\end{array}$ & $\begin{array}{l}\text { Two Photon } \\
\text { Imaging Method }\end{array}$ & Cell Type & Application & Ref \\
\hline $\mathrm{L}-M A G_{0}$ & PTL & $\begin{array}{l}1 \mathrm{P} 376 \mathrm{~nm} 2 \mathrm{P} \text { maximal } \\
\text { responses at } 820 \mathrm{~nm}\end{array}$ & $\begin{array}{c}\sigma 2=10 \mathrm{GM} \text { at } 820 \mathrm{~nm}^{\mathrm{a}} \\
\text { and } \sigma 2=300 \mathrm{GM} \text { at } 630 \\
\mathrm{~nm}(- \text { trans })^{\mathrm{a}}\end{array}$ & $\begin{array}{l}\text { 2P-laser scanning } \\
\text { at } 820 \mathrm{~nm}\end{array}$ & HEK293 & $\begin{array}{l}\text { 2PE elicited optimal photocurrents of } \mathrm{I}_{\max } \sim 120 \mathrm{pA} \text { in } \\
\text { GluK2-L439C-(LiGluR) expressing HEK293 cells. Responses were } \\
\text { 10-20\% of those obtained by } 1 \mathrm{P} \text {. }\end{array}$ & [65] \\
\hline MAG2p & PTL & $\begin{array}{l}1 \mathrm{P} \sim 420 \mathrm{~nm} 2 \mathrm{P} \\
\text { maximal response at } \\
\quad 900 \mathrm{~nm}\end{array}$ & $\sigma 2=56 \mathrm{GM}$ at $780 \mathrm{~nm}^{\mathrm{b}}$ & $\begin{array}{l}\text { 2P-laser scanning } \\
\text { at } 900 \mathrm{~nm}\end{array}$ & $\begin{array}{l}\text { HEK293 and dissociated } \\
\text { hippocampal neurons }\end{array}$ & $\begin{array}{l}\text { Cells expressing LiGluR, in voltage clamp } 2 \mathrm{PE} \text { elicited } \\
\text { photocurrents recordings of } \sim 50 \text { and } \sim 20 \mathrm{pA} \text { in HEK and neurons, } \\
\text { respectively. These were } 10-20 \% \text { of those obtained by } 1 \mathrm{P} \\
\text { illumination. }\end{array}$ & [65] \\
\hline MAGA2p & PTL & $\begin{array}{l}1 \mathrm{P} \sim 420 \mathrm{~nm} 2 \mathrm{P} \\
\text { maximal response at } \\
880 \mathrm{~nm}\end{array}$ & $\begin{array}{l}\text { Naphthalene (antenna), } \sigma 2 \\
\approx 200 \mathrm{GM} \text { at } 780 \mathrm{~nm}^{\mathrm{c}}\end{array}$ & $\begin{array}{l}\text { 2P-laser scanning } \\
\text { at } 900 \mathrm{~nm}\end{array}$ & HEK293 & $\begin{array}{l}\text { Cells expressing LiGluR, in voltage clamp 2PE elicited } \\
\text { photocurrents recordings of } 6 \text { pA. }\end{array}$ & [65] \\
\hline MAGA ligand-2 & PTL & 1P $\sim 380 \mathrm{~nm}$ & $\begin{array}{c}\text { Pyrene (antenna), } \sigma_{2}=55 \\
\text { GM }\end{array}$ & $\begin{array}{l}\text { Not tested under } \\
2 \mathrm{PE}\end{array}$ & N.A. & N.A. & [66] \\
\hline L-MAG 460 & PTL & $1 \mathrm{P} \sim 460 \mathrm{~nm}$ & $\begin{array}{c}\sigma 2=80 \mathrm{GM} \text { at } 850 \mathrm{~nm} \\
(- \text { trans })\end{array}$ & $\begin{array}{l}\text { 2P digital } \\
\text { holography } \\
\text { (2P-DH) at } 850 \mathrm{~nm}\end{array}$ & $\begin{array}{l}\text { HeLa cells and dissociated } \\
\text { hippocampal neurons }\end{array}$ & $\begin{array}{l}\text { Photocurrents elicited by 2P-DH were } \sim 80 \mathrm{pA} \text { in size, } \sim 39 \% \text { of } \\
\text { those obtained by 1P photocurrents from the same cell. HeLA cells } \\
\text { expressing R-GECO showed reliable fluorescent responses when } \\
\text { imaged at } 561 \mathrm{~nm} \text { and excited at } 840 \mathrm{~nm} \text {. }\end{array}$ & [41] \\
\hline D-MAG 460 & PTL & Similar prope & ties as $\mathrm{L}-\mathrm{MAG}_{460}$ & $\begin{array}{c}\text { 2P digital } \\
\text { holography } \\
\text { (2P-DH) At } 850 \mathrm{~nm}\end{array}$ & HEK293 cells & $\begin{array}{l}\text { Cells expressing mGluR3-Q306C (LimGluR3) illuminated by } \\
\text { 2P-DH exhibited mean photocurrents of } \sim 100 \mathrm{pA} \text {, namely } \sim 85 \% \text { of } \\
\text { those obtained by } 1 \mathrm{P} \text {. }\end{array}$ & [41] \\
\hline$M A G_{2 p_{-} F}^{\text {slow }}$ & PTL & $1 \mathrm{P} \sim 360 \mathrm{~nm}$ & $\sigma 2=69 \mathrm{GM}^{\mathrm{d}}$ & $\begin{array}{l}\text { 2P-laser scanning } \\
\text { at } 780 \mathrm{~nm}\end{array}$ & $\begin{array}{l}\text { HEK293 cells, rat } \\
\text { hippocampal organotypic } \\
\text { slices and C. elegans' TRN } \\
\text { neurons }\end{array}$ & $\begin{array}{l}\text { Cells expressing LiGluR and R-GECO or RCaMP showed that 2PE } \\
\text { elicited photoresponses }(\Delta F / F) \text { similar to those obtained by } 1 \mathrm{P} \\
\text { illumination (at } 405 \mathrm{~nm} \text { ). Similar photoresponses from } 1 \mathrm{P} \text { and } 2 \mathrm{P} \\
\text { were seen in vivo, in TRN neurons in C. elegans expressing } \\
\text { GCaMP6s. }\end{array}$ & [67] \\
\hline toCl-MAG1 & PTL & $1 \mathrm{P} \sim 470 \mathrm{~nm}$ & N.A. & $\begin{array}{l}\text { Not tested under } \\
2 \mathrm{PE}\end{array}$ & N.A. & N.A. & [68] \\
\hline ATG & PCL & $1 \mathrm{P} \sim 330 \mathrm{~nm}$ & N.A. & $\begin{array}{l}\text { 2P-laser scanning } \\
\text { at } 740 \mathrm{~nm}\end{array}$ & Hippocampal neurons & $\begin{array}{l}\text { cis-ATG-mediated synaptic currents of } \sim 50 \mathrm{pA} \text { in size following } \\
\text { 2P-photolysis. }\end{array}$ & [69] \\
\hline PAI & PCL & 1P $\sim 320 \mathrm{~nm}$ & N.A. & $\begin{array}{l}\text { 2P-laser scanning } \\
\text { at } 840 \mathrm{~nm}\end{array}$ & HEK293 cells & $\begin{array}{l}\text { Cells co-expressing mAChR (m2R) and } \mathrm{G} \alpha \mathrm{q}(\mathrm{TOP}) \text { loaded with the } \\
\text { calcium indicator Oregon-green (OGB-AM) displayed reliable } \\
\text { fluorescent responses ( } \triangle \mathrm{F} / \mathrm{F} / \mathrm{F}) \text { to trans-PAI by } 2 \mathrm{PE} \text {. }\end{array}$ & [70] \\
\hline Alloswitch & PCL & $\begin{array}{l}1 \mathrm{P} \text { and } 2 \mathrm{P} \text { absorbance } \\
\text { N.A. } 2 \mathrm{P} \text { maximal } \\
\text { response obtained by } \\
760 \mathrm{~nm}\end{array}$ & N.A. & 2P-laser scanning & $\begin{array}{l}\text { HEK cells and organotypic } \\
\text { hippocampal slices. }\end{array}$ & $\begin{array}{l}\text { HEK cells expressing mGluR5-eYFP loaded with Fura-2 AM or } \\
\text { neurons in organotypic hippocampal slices expressing GCaMP6s } \\
\text { and DsRed were photostimulated by } 2 \text { PE. trans-alloswitch released } \\
\text { local inhibition of mGlu5 and enabled DHPG } \\
\text { (mGluR5-agonist)-dependent activation of the receptor. Responses } \\
\text { were monitored using Ca' } \mathrm{an}^{+} \text {-indicators. } 760 \mathrm{~nm} \text { elicited highest } \\
\text { increase in the frequency of calcium-oscillations. }\end{array}$ & [71] \\
\hline Glu_brAzo2 & PCL & $\begin{array}{l}\text { 1P -cis } \sim 395 \mathrm{~nm} \text {-trans } \\
\sim 480 \mathrm{~nm}\end{array}$ & N.A. & $\begin{array}{l}\text { Not tested under } \\
\text { 2PE }\end{array}$ & N.A. & N.A. & [72] \\
\hline $4 \mathrm{FAB}-\mathrm{QA}$ & PCL & 1P $\sim 415 \mathrm{~nm}$ & N.A. & $\begin{array}{l}\text { 2P-laser scanning } \\
\text { at } 780 \text { and } 1000 \mathrm{~nm}\end{array}$ & $\begin{array}{l}\text { CA1 neurons from } \\
\text { hippocampal organotypic } \\
\text { slices }\end{array}$ & $\begin{array}{l}\text { 2PE elicited } \sim 32 \% \text { inhibition of voltage gated } \mathrm{Na}^{+} \text {and } \mathrm{K}^{+} \text {channels } \\
\text { than that obtained by } 1 \mathrm{P} \text {. }\end{array}$ & [73] \\
\hline
\end{tabular}

${ }^{\text {a }}$ Data from Carroll et al. [41]. ${ }^{\text {; }}$ Data from Cabré et al. [67]. ${ }^{\text {; }}$ Data from Gascón-Moya et al. [66]. ${ }^{\text {}}$; Data estimated based on density functional theory, N.A = not available. 
One strategy employed involved breaking the symmetry around the azobenzene core (below in Figure 3 and Table 1) [74]. This was obtained by creating a push-pull system, where one benzene ring of the azo-core was decorated with an electron donating group, while the second azo-unit was supplemented with an electron withdrawing group. These led to an asymmetric azobenzene with a significantly red-shifted absorbance $[21,68,74-77]$. This strategy was employed in one of the very first 2P-compatible PTLs, where the MAG photoswitch was redesigned to include an asymmetric aminoazobenzene core (tertiary amine in the $4^{\prime}$-position) to act as a strong electron-donating group, denoted MAG2p (Figure 3) [65]. Indeed, this photoswitch exhibited a red-shifted 1P-absorption spectrum peaking at $420 \mathrm{~nm} ; \sim 60 \mathrm{~nm}$ red-shifted compared to the parent MAG. Notably, this photoswitch could be activated by 2PE (Table 1). In a subsequent report, the authors estimated its 2P-absopriton cross section and suggest it to be $\sim$ five times higher than that of the parent photoswitch (MAG2p, o2 = 56 GM [72] at $850 \mathrm{~nm}$, Table 1). The authors go on to show that, when coupled to a glutamate receptor (LiGluR [63]) optimal 2P-responses are obtained at $900 \mathrm{~nm}$. Another unique feature of this photoswitch is that it is no longer bi-stable, rather spontaneously reverts back to -trans in the dark. Notably, decrease in the thermal stability of the -cis isomer by red-shifting of absorbance of azobenzenes is a well-described phenomenon [74]. The functional outcome of the thermal relaxation of the photoswitch is a rapid cessation of channel activation, seen as a decrease in current once illumination stops ( $\tau_{\text {off }}=150 \mathrm{~ms}$ [67]; 10,000-fold times faster than thermal relaxation of MAG, $\tau_{\text {off }}=$ $25 \min [75])$.

A push-pull scheme was similarly employed, very shortly after, by Kienzler et al. [75]. Here, the authors have modified MAG to include an asymmetric azobenzene-core with a tertiary amine at the $4^{\prime}$-position as the electron-donor, but an acetamido-group at the $4^{\prime}$-position, as the weak electron withdrawing group (Figure 3). These modifications resulted in a larger shift in peak 1P-absorption $(\sim 100 \mathrm{~nm})$ of the -trans isomer $\left(\lambda_{\text {peak }}=460 \mathrm{~nm}\right)$, therefore denoted $\mathrm{MAG}_{460}$ (Figure 3) [75]. Expectedly, this modification reduced the stability of the -cis isomer $\left(\mathrm{MAG}_{460}, \tau_{\mathrm{off}}=0.71 \mathrm{~s}\right)$ [75]. Importantly, this shift led to an 8-fold increase in the photoswitch's 2P-absorption cross section (trans-MAG $460, \sigma 2=80$ GM at $850 \mathrm{~nm}$ ) [41]. We have later employed this photoswitch to successfully activate LiGluR [41]. Though the photocurrents obtained by 2PE were of smaller amplitude than when using 1P-illumination, they were sufficient to evoke action potential firing in cultured neurons by parallel excitation methods (digital-holography; Table 1) [41,78]. Lastly, we also employed a fluorescent reporter as readout for $\mathrm{Ca}^{2+}$-activity (R-GECO) and find it to provide reliable responses $(\triangle F / F)$, demonstrating that this method is also suitable for all-optical interrogation of cells [78].

Another interesting strategy that has been employed to sensitize the MAG photoswitch towards NIR wavelengths is by adding a light-harvesting molecule (i.e., antenna). Two such photoswitches were designed under the name of maleimide-azobenzene-glutamate antenna, or MAGA. The first-MAGA2p [65] — consisted of the same asymmetric core as us found in MAG2p along an added light-harvesting naphthalene-derivative (with a high $2 \mathrm{P}$-absorption cross section; $\sigma 2 \approx 200 \mathrm{GM}$ at $780 \mathrm{~nm}$ [79]) (Figure 3). The antenna was incorporated to sensitize the trans-azobenzene by resonant electronic energy transfer (RET) (Figure 3). This photoswitch could therefore be photoactivated by two distinct mechanisms: direct excitation of the push-pull azo-core by $2 \mathrm{PE}$ and RET by the photosensitizing antenna. This photoswitch displayed low thermal stability, with rapid relaxation of the currents ( $\tau_{\text {off }}=265 \mathrm{~ms}$ [65]) that, when excited using a laser-scanning method, would not allow efficient activation of the channel or robust cellular responses. In a subsequent improved version, MAGA ligand-2 (Figure 3) [66], the authors maintained an antenna for harvesting light, albeit swapped it by a pyrene molecule $\left(\sigma_{2}=55 \mathrm{GM}\right)$, but reverted back to a symmetrical azo-core with the intention to counteract the pyrene's lower $2 \mathrm{P}$-absorption cross section ( $\sim 4$-fold lower than naphthalene) by increasing the thermal stability of the photoswitch. Indeed, the resulting photoswitch exhibited a highly stable -cis isomer (MAGA ligand-2, $\tau_{\text {off }}=2.0 \mathrm{~h}$ in DMSO). Thus, the increased thermal stability of the -cis state should make this photoswitch more suitable to accumulate activated photoswitches by scanning imaging methods. However, it is worthy to mention that the photosensitizing antenna 
employed drastically reduced the solubility of the photoswitch and, likely, its usability in biological experiments. Indeed, so far MAGA ligand-2 was not employed with cells (Table 1).

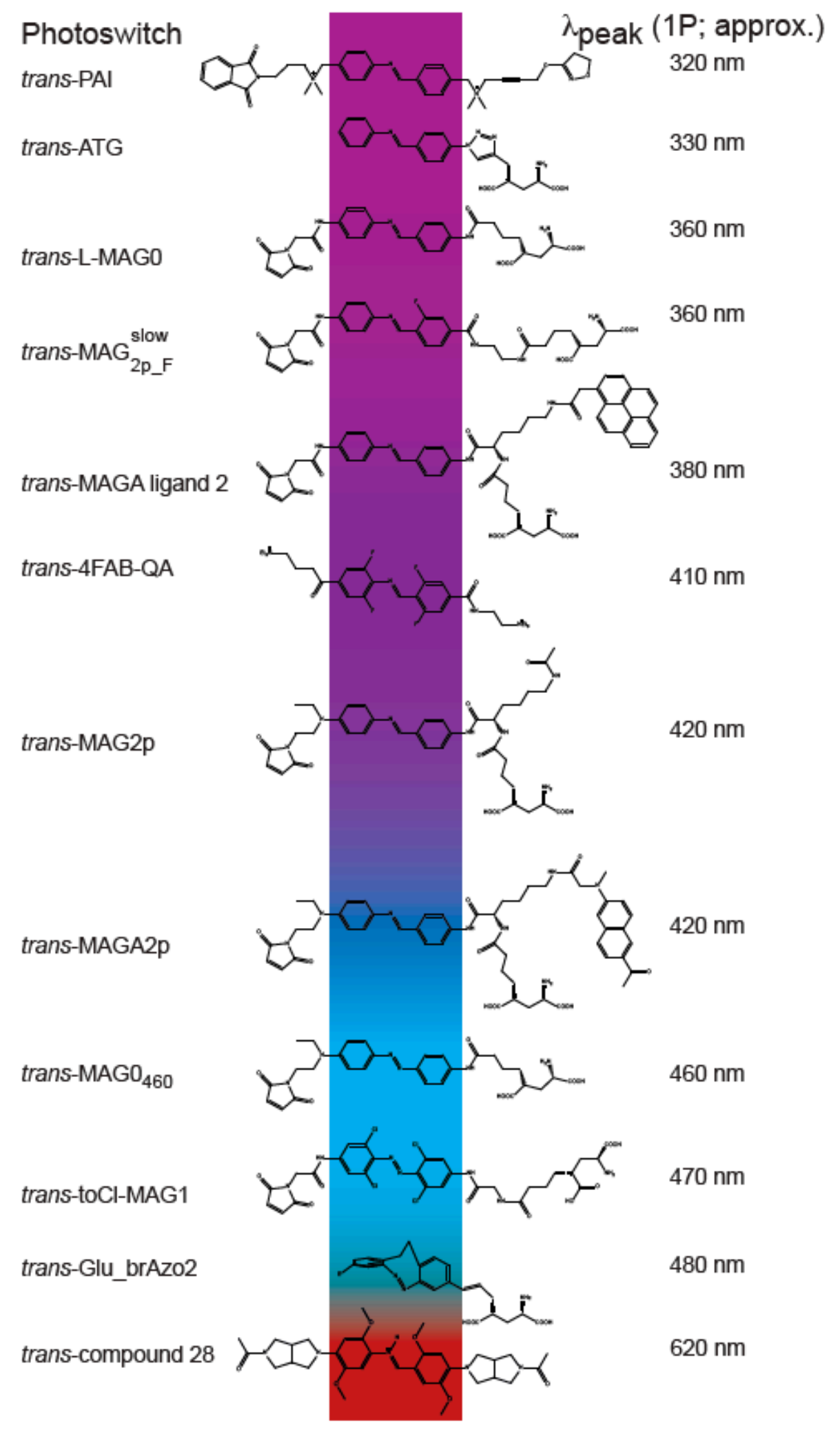

Figure 3. Chemical structure and absorption of exemplary 2P-compatible photoswitches. Left, names of photoswitches; right, one photon (1P) peak absorption $\left(\lambda_{\max }\right)$, also depicted by middle color gradient. 
The most recent development in MAG photochemistry includes a compromise between the -cis' thermal stability and 2P-absorptivity by addition of a strong inductive electron withdrawing group in the ortho position, in conjunction with an asymmetric azo-core (Figure 3). This new design has been based on previous ortho substitutions made onto azobenzene molecules that can affect the steric or electronic barrier for isomerization, not to mention to robustly slow down its thermal relaxation rates $[68,74]$. Examples of this include the symmetrical azo-core photoswitch denoted toCl-MAG1 (Figure 3); highly decorated with tetra-ortho-chloro substitutions, exhibiting a very slow thermal relaxation ( $\tau_{\text {cis }}=3.5 \mathrm{~h}$ at $37^{\circ} \mathrm{C}$ in $\left.\mathrm{PBS}, \mathrm{pH}=7.0\right)$ [68], not to mention red-shifting its peak $1 \mathrm{P}$ absorption to $470 \mathrm{~nm}$ (the most rightward shift seen in PTLs) (Figure 3). When computationally modeled onto the azo-core of MAG0 and MAG2p, these substitutions yielded new photoswitches, designated $M A G_{2 p_{-} F}^{\text {slow }}$ (Figure 3) [67]. Surprisingly, these substitutions did not lead to a major shift in the 1P absorption of the photoswitch $\left(\lambda_{\text {peak }}=\sim 360 \mathrm{~nm}\right)$, however they significantly increased the thermal stability of the -cis variant when compared to previous MAG2p (MAG2p, $\tau_{\text {cis }}=118 \mathrm{~ms}$ in 80\% PBS:20\% DMSO [65]; $M A G_{2 p_{-} F^{\text {slow }}}, \tau_{\text {cis }}=10 \mathrm{~min}$ in 99\% PBS:1\% DMSO [67]). Modeling also showed that the photoswitch should exhibit a slightly increased 2P-absoprtion cross section (MAG2p, $02=56 \mathrm{GM} ; M A G_{2 p_{-} F^{\prime}}^{\text {slow }}, \mathrm{\sigma}=$ $69 \mathrm{GM}$ ), therefore potentially resolving the problem of insufficient accumulation of opened channels during illumination. Although the authors do not show comparison of $1 \mathrm{P}$ vs. $2 \mathrm{P}$-mediated current size (which should differ), they do however extensively characterize the responses obtained by a fluorescent calcium activity reporter (RCaMP2) and show that equivalent responses are obtained when using optimal 1P-(405 nm) or 2P-excitation $(780 \mathrm{~nm})$ (Table 1). These results are in-line with our own, showing the compatibility of this photoswitch, and technique, for all-optical interrogation of cells.

\section{Novel Photoswitches with 2PE-Potential}

Other azobenzene-based photoswitches have also been rendered 2p-compatible by use of other strategies. Of these, the methoxy-substitutions at the meta positions and C2-bridged azobenzene are particularly interesting [74]. Methoxy meta-substitutions are estimated to strongly shift the absorbance of the azo-core to much longer wavelengths than most reported photoswitches (i.e., $>100 \mathrm{~nm}$ ), specifically into the far-red and infra-red regimes [80] and these should likely have a high 2P-absoprion cross section. However, these modifications will most likely lead to very rapid thermal relaxations. One such example is compound 28 with near-IR absorbance peaking at $620 \mathrm{~nm}$ (but also sufficiently activated by $730 \mathrm{~nm}$ ), but with an ultra-rapid thermal back reaction $\left(\tau_{\text {cis }}=10 \mu \mathrm{s}\right.$ ) (Figure 3) [74].

The second approach, the C2-bridged azobenzene, also show a significant red-shifted absorption spectrum of the -trans isomer $\left(\lambda_{\max }>540 \mathrm{~nm}\right)[72,74,81]$, implying an increased 2P-absorption cross section [41], but with a much more favorable (i.e., slower) thermal relaxation rate (on the order of minutes at room temperature in aqueous solution) than methoxy meta-substitutions. The drawback of the molecule is that the -cis state is the more thermodynamically stable form. This means that if the photoswitch is active in -cis, it would be active when applied onto the preparation. Thus, it is preferable should the photoswitch be active only in -trans. An additional drawback is that the stable -cis isomer poorly absorbs red light and isomerization to -trans requires UV to near UV illumination. Recently, two trans-active diffusible photoswitches were designed based on a C2-bridged azobenzene, denoted locked-azobenzene (LAB) [82] or Glu_brAzo [72]. Both photoswitches bear a glutamate moiety as ligand, thus intended for activation of glutamate receptors, and exhibit highly similar structural and spectral properties (Figure 3). Of note, despite their similarities, LAB is shown to selectively activate NMDARs, whereas Glu_brAzo efficiently activates both Kainate and AMPA receptors. Regardless the receptor type, Glu_brAzo shows more practical features for use in vivo, particularly increased solubility in aqueous media owing to the addition of a bulky ionic group. This is noteworthy as solubility issues are a very common limitation of most photoswitches, in particular azobenzene-based ones $[9,21]$. This additional group is also suggested to improve the performance of the photoswitch by increasing the steric congestion around the glutamate moiety with the intention to lower the interaction of the glutamate moiety with the receptor when the photoswitch is found in its stable -cis isomeric 
form. To design Glu_brAzo, the authors searched for trans-active photoswitches that target glutamate receptors. This was not very challenging as most diffusible GluR-photoswitches are, surprisingly, active in the extended thermally stable -trans form (e.g., [83,84]). They honed-in on a trans-active photoswitch denoted GluAzo [85]. For photoactivation, cis-Glu_brAzo (i.e., inactive) requires $\lambda_{\text {peak }}=$ $395 \mathrm{~nm}$ to shift to -trans. As noted above, this is quite a limitation for two-photon activation. However, this photoswitch exhibits very desirable bi-stability, with very slow spontaneous back-isomerization from trans-to-cis $\left(\mathrm{t}_{1 / 2} \sim 4 \mathrm{~h}\right.$, at RT in aqueous media). This step could be accelerated by green light illumination $\left(\lambda_{\text {peak }}=480 \mathrm{~nm}\right)$, suggesting that it may also be compatible with $2 \mathrm{PE}$. However, the 2P-absorption cross section was not assessed for Glu_brAzo (or LAB) and is very hard to predict based solely on 1P absorbance (seen above and e.g., [47]). An additional limitation of Glu_brAzo is its overlapping absorption spectra of both -cis and -trans isomers, so much so that even the use of optimal 1P wavelengths result in a mixture of photostationary states, with merely $\sim 60 \%$ of the active -trans isomer.

\section{Future Prospects}

There is growing interest in synthetic optogenetic tools in fields such as in neuroscience $[8,12,23]$, heart physiology [86-88] and, intuitively, vision restoration [89-92]. Thus, we expect these to motivate further developments of the strategy in the upcoming years, in particular towards progression of the technique towards enhancing multiphoton absorption. Synthetic optogenetic tools can be combined with electrophysiological recordings and optical tools (e.g., $\mathrm{Ca}^{2+}$-probes [78]), making it highly tailored for in vivo use in different animal models in an all-optical manner. We also suggest that several photoswitches might even make it to the clinic [93], in particular photoswitches that target native proteins (e.g., [28,29]) or those applicable in the blood [74]. In addition, synthetic optogenetic tools have shown promise for studying (and maybe treating) Parkinson's disease-related receptors [94], inhibiting cellular division in cancer [95], not to mention controlling cellular excitability, highly relevant for brain diseases such as epilepsy [96].

Here, we have briefly summarized several of the newest developments in the field of synthetic optogenetics, more precisely efforts devoted towards rendering photoswitches absorbent of longer, red-shifted wavelengths and their ability to undergo 2PE. These properties are highly desired for making the method more operational in vivo. Despite this motivation, it remains that most laboratories focus on designing unique photoswitches for 1P-applications. We believe that this stems from limited information on nonlinear multiphoton properties of photoswitches and the difficulties in determining, a priori, their multiphoton absorption properties [47,67], relaxation rates and whether optimization (derivatization) of $1 \mathrm{P}$-functional photoswitches towards $2 \mathrm{PE}$ will not render them inoperative.

It appears that bistable photoswitches provide an optimal starting point for designing next-generation 2PE-compatible photoswitches. The slow relaxing photoswitches with light-harvesting antennae and symmetrical azo-cores display high 2P-absorption cross section that should allow for robust photoactivation of optical actuators in vivo. However, they will require further modifications to increase their solubility in aqueous solution prior use with cells. The bistable $M A G_{2 p_{-} F}^{\text {slow }}$ exhibits slightly better features. Though of lower $2 \mathrm{P}$ cross-section $(<70 \mathrm{GM})$ and almost no shift in $1 \mathrm{P}$ absorption maxima, its lower thermal relaxation allows for larger responses. The effect of this, and other, photoswitches could be further improved by additional means such as use of higher 2P-laser intensities (keeping in mind that higher intensities may be harmful to cells [52]), increase in the expression of the optical actuators [97,98] and, importantly, use of parallel excitation methods for simultaneous activation of larger regions of interest in all axes [55,57,78,99].

In summary, we see current hurdles as wonderful incentives and opportunities for designing better photoswitches and protein actuators. Indeed, many labs around the world are working intensely to address these issues. Consequently, we anticipate that the potential of synthetic optogenetics towards in vivo use and the clinic will be realized within the next few years. 
Author Contributions: Conceptualization, S.B. and S.K.; methodology, S.B.; data curation, S.B. and S.K.; writing-review and editing, S.B. and S.K.; visualization, S.B.; supervision, S.B.; funding acquisition, S.B. The research submitted is in partial fulfilment for a Doctoral degree for S.K. All authors have read and agreed to the published version of the manuscript.

Funding: This research was funded by the Israel Science Foundation (ISF), grant number 1096/17 (S.B.).

Conflicts of Interest: The authors declare no conflict of interest.

\section{References}

1. Kottke, T.; Xie, A.; Larsen, D.S.; Hoff, W.D. Photoreceptors take charge: Emerging principles for light sensing. Ann. Rev. Biophys. 2018, 47, 291-313. [CrossRef] [PubMed]

2. Mathes, T.; Kennis, J.T.M. Editorial: Optogenetic tools in the molecular spotlight. Front. Mol. Biosci. $2016,3$. [CrossRef] [PubMed]

3. Eleftheriou, C.; Cesca, F.; Maragliano, L.; Benfenati, F.; Maya-Vetencourt, J.F. Optogenetic modulation of intracellular signalling and transcription: Focus on neuronal plasticity. J. Exp. Neurosci. 2017, 11. [CrossRef] [PubMed]

4. Deisseroth, K.; Feng, G.; Majewska, A.K.; Miesenböck, G.; Ting, A.; Schnitzer, M.J. Next-generation optical technologies for illuminating genetically targeted brain circuits. J. Neurosci. 2006, 26, 10380-10386. [CrossRef]

5. Boyden, E.S.; Zhang, F.; Bamberg, E.; Nagel, G.; Deisseroth, K. Millisecond-timescale, genetically targeted optical control of neural activity. Nat. Neurosci. 2005, 8, 1263-1268. [CrossRef]

6. Nagel, G.; Ollig, D.; Fuhrmann, M.; Kateriya, S.; Musti, A.M.; Bamberg, E.; Hegemann, P. Channelrhodopsin-1: A light-gated proton channel in green algae. Science 2002, 296, 2395-2398. [CrossRef]

7. Deisseroth, K.; Hegemann, P. The form and function of channelrhodopsin. Science 2017, 357 , eaan5544. [CrossRef]

8. Deisseroth, K. Optogenetics: 10 years of microbial opsins in neuroscience. Nat. Neurosci. 2015, 18, 1213-1225. [CrossRef]

9. Berlin, S.; Isacoff, E.Y. Synapses in the spotlight with synthetic optogenetics. EMBO Rep. 2017, 18, 677-692. [CrossRef]

10. Berlin, S.; Isacoff, E.Y. Optical Control of Glutamate Receptors of the NMDA-Kind in Mammalian Neurons, with the Use of Photoswitchable Ligands; Springer Science+Business Media LLC: Berlin, Germany, 2017; Volume 130.

11. Ziegler, T.; Möglich, A. Photoreceptor engineering. Front. Mol. Biosci. 2015, 2. [CrossRef]

12. Paoletti, P.; Ellis-Davies, G.C.R.; Mourot, A. Optical control of neuronal ion channels and receptors. Nat. Rev. Neurosci. 2019, 20, 514-532. [CrossRef]

13. Folgering, J.H.A.; Kuiper, J.M.; de Vries, A.H.; Engberts, J.B.F.N.; Poolman, B. Lipid-mediated light activation of a mechanosensitive channel of large conductance. Langmuir 2004, 20, 6985-6987. [CrossRef] [PubMed]

14. Guerrero, L.; Smart, O.S.; Woolley, G.A.; Allemann, R.K. Photocontrol of DNA binding specificity of a miniature engrailed homeodomain. J. Am. Chem. Soc. 2005, 127, 15624-15629. [CrossRef] [PubMed]

15. Frank, J.A.; Franquelim, H.G.; Schwille, P.; Trauner, D. Optical control of lipid rafts with photoswitchable ceramides. J. Am. Chem. Soc. 2016, 138, 12981-12986. [CrossRef] [PubMed]

16. Habermacher, C.; Martz, A.; Calimet, N.; Lemoine, D.; Peverini, L.; Specht, A.; Cecchini, M.; Grutter, T. Photo-switchable tweezers illuminate pore-opening motions of an ATP-gated P2X ion channel. eLife 2016, 5. [CrossRef] [PubMed]

17. Kienzler, M.A.; Isacoff, E.Y. Precise modulation of neuronal activity with synthetic photoswitchable ligands. Curr. Opin. Neurobiol. 2017, 45, 202-209. [CrossRef]

18. Kramer, R.H.; Mourot, A.; Adesnik, H. Optogenetic pharmacology for control of native neuronal signaling proteins. Nat. Neurosci. 2013, 16, 816-823. [CrossRef]

19. Kaufman, H.; Vratsanos, S.M.; Erlanger, B.F. Photoregulation of an enzymic process by means of a light-sensitive ligand. Science 1968, 162, 1487-1489. [CrossRef]

20. Szymański, W.; Beierle, J.M.; Kistemaker, H.A.V.; Velema, W.A.; Feringa, B.L. Reversible photocontrol of biological systems by the incorporation of molecular photoswitches. Chem. Rev. 2013, 113, 6114-6178. [CrossRef]

21. Beharry, A.A.; Woolley, G.A. Azobenzene photoswitches for biomolecules. Chem. Soc. Rev. 2011, 40, 4422. [CrossRef] 
22. Zhu, M.; Zhou, H. Azobenzene-based small molecular photoswitches for protein modulation. Org. Biomol. Chem. 2018, 16, 8434-8445. [CrossRef] [PubMed]

23. Hüll, K.; Morstein, J.; Trauner, D. In vivo photopharmacology. Chem. Rev. 2018, 118, 10710-10747. [CrossRef] [PubMed]

24. Fehrentz, T.; Schönberger, M.; Trauner, D. Optochemical Genetics. Angew. Chem. Int. Ed. 2011, 50, 12156-12182. [CrossRef] [PubMed]

25. Reiner, A.; Isacoff, E.Y. Photoswitching of cell surface receptors using tethered ligands. In Photoswitching Protein; Cambridge, S., Ed.; Springer: New York, NY, USA, 2014; Volume 1148, pp. 45-68. [CrossRef]

26. Berlin, S.; Szobota, S.; Reiner, A.; Carroll, E.C.; Kienzler, M.A.; Guyon, A.; Xiao, T.; Trauner, D.; Isacoff, E.Y. A family of photoswitchable NMDA receptors. elife 2016, 5. [CrossRef] [PubMed]

27. Broichhagen, J.; Damijonaitis, A.; Levitz, J.; Sokol, K.R.; Leippe, P.; Konrad, D.; Isacoff, E.Y.; Trauner, D. Orthogonal optical control of a $\mathrm{G}$ protein-coupled receptor with a SNAP-Tethered photochromic ligand. ACS Cent. Sci. 2015, 1, 383-393. [CrossRef] [PubMed]

28. Izquierdo-Serra, M.; Bautista-Barrufet, A.; Trapero, A.; Garrido-Charles, A.; Díaz-Tahoces, A.; Camarero, N.; Pittolo, S.; Valbuena, S.; Pérez-Jiménez, A.; Gay, M.; et al. Optical control of endogenous receptors and cellular excitability using targeted covalent photoswitches. Nat. Commun. 2016, 7. [CrossRef]

29. Donthamsetti, P.C.; Broichhagen, J.; Vyklicky, V.; Stanley, C.; Fu, Z.; Visel, M.; Levitz, J.L.; Javitch, J.A.; Trauner, D.; Isacoff, E.Y. Genetically Targeted Optical Control of an Endogenous G Protein-Coupled Receptor. J. Am. Chem. Soc. 2019, 141, 11522-11530. [CrossRef]

30. Banghart, M.; Borges, K.; Isacoff, E.; Trauner, D.; Kramer, R.H. Light-activated ion channels for remote control of neuronal firing. Nat. Neurosci. 2004, 7, 1381-1386. [CrossRef]

31. Fodje, M.N.; Al-Karadaghi, S. Occurrence, conformational features and amino acid propensities for the pi-helix. Protein Eng. 2002, 15, 353-358. [CrossRef]

32. Lester, H.A.; Krouse, M.E.; Nass, M.M.; Wassermann, N.H.; Erlanger, B.F. Light-activated drug confirms a mechanism of ion channel blockade. Nature 1979, 280, 509-510. [CrossRef]

33. McKenzie, C.K.; Sanchez-Romero, I.; Janovjak, H. Flipping the photoswitch: Ion channels under light control. In Novel Chemical Tools to Study Ion Channel Biology; Ahern, C., Pless, S., Eds.; Springer: New York, NY, USA, 2015; Volume 869, pp. 101-117. [CrossRef]

34. Kamei, T.; Akiyama, H.; Morii, H.; Tamaoki, N.; Uyeda, T.Q.P. Visible-Light photocontrol of $(E) /(Z)$ isomerization of the 4-(Dimethylamino)azobenzene pseudo-nucleotide unit incorporated into an oligonucleotide and DNA hybridization in aqueous media. Nucleosides Nucleotides Nucleic Acids 2009, 28, 12-28. [CrossRef] [PubMed]

35. Ramakrishnan, P.; Maclean, M.; MacGregor, S.J.; Anderson, J.G.; Grant, M.H. Cytotoxic responses to 405nm light exposure in mammalian and bacterial cells: Involvement of reactive oxygen species. Toxicol. In Vitro 2016, 33, 54-62. [CrossRef] [PubMed]

36. Trigo, F.F.; Corrie, J.E.T.; Ogden, D. Laser photolysis of caged compounds at $405 \mathrm{~nm}$ : Photochemical advantages, localisation, phototoxicity and methods for calibration. J. Neurosci. Methods 2009, 180, 9-21. [CrossRef] [PubMed]

37. Zhang, H.; Salo, D.; Kim, D.M.; Komarov, S.; Tai, Y.-C.; Berezin, M.Y. Penetration depth of photons in biological tissues from hyperspectral imaging in shortwave infrared in transmission and reflection geometries. J. Biomed. Opt. 2016, 21. [CrossRef] [PubMed]

38. Weissleder, R. A clearer vision for in vivo imaging. Nat. Biotechnol. 2001, 19, 316-317. [CrossRef]

39. Wang, Z.; Hu, M.; Ai, X.; Zhang, Z.; Xing, B. Near-infrared manipulation of membrane ion channels via upconversion optogenetics. Adv. Biosyst. 2019, 3, 1800233. [CrossRef]

40. Ellis-Davies, G.C.R. Two-photon microscopy for chemical neuroscience. ACS Chem. Neurosci. 2011, 2, 185-197. [CrossRef]

41. Carroll, E.C.; Berlin, S.; Levitz, J.; Kienzler, M.A.; Yuan, Z.; Madsen, D.; Larsen, D.S.; Isacoff, E.Y. Two-photon brightness of azobenzene photoswitches designed for glutamate receptor optogenetics. Proc. Natl. Acad. Sci. USA 2015, 112, E776-E785. [CrossRef]

42. Hartley, G.S. The Cis-form of Azobenzene. Nature 1937, 140, 281. [CrossRef]

43. Shao, J.; Lei, Y.; Wen, Z.; Dou, Y.; Wang, Z. Nonadiabatic simulation study of photoisomerization of azobenzene: Detailed mechanism and load-resisting capacity. J. Chem. Phys. 2008, 129, 164111. [CrossRef] 
44. Bandara, H.M.D.; Burdette, S.C. Photoisomerization in different classes of azobenzene. Chem. Soc. Rev. 2012, 41, 1809-1825. [CrossRef] [PubMed]

45. Hamm, P.; Ohline, S.M.; Zinth, W. Vibrational cooling after ultrafast photoisomerization of azobenzene measured by femtosecond infrared spectroscopy. J. Chem. Phys. 1997, 106, 519-529. [CrossRef]

46. Lednev, I.K.; Ye, T.Q.; Matousek, P.; Towrie, M.; Foggi, P.; Neuwahl, F.V.; Umapathy, S.; Hester, R.E.; Moore, J.N. Femtosecond time-resolved UV-visible absorption spectroscopy of trans-azobenzene: Dependence on excitation wavelength. Chem. Phys. Lett. 1998, 290, 68-74. [CrossRef]

47. Drobizhev, M.; Makarov, N.S.; Tillo, S.E.; Hughes, T.E.; Rebane, A. Two-photon absorption properties of fluorescent proteins. Nat. Methods 2011, 8, 393-399. [CrossRef]

48. Stoltzfus, C.R.; Barnett, L.M.; Drobizhev, M.; Wicks, G.; Mikhaylov, A.; Hughes, T.E.; Rebane, A. Two-photon directed evolution of green fluorescent proteins. Sci. Rep. 2015, 5, 1-9. [CrossRef]

49. Quick, M.; Dobryakov, A.L.; Gerecke, M.; Richter, C.; Berndt, F.; Ioffe, I.N.; Granovsky, A.A.; Mahrwald, R.; Ernsting, N.P.; Kovalenko, S.A. Photoisomerization dynamics and pathways of trans- and cis-azobenzene in solution from broadband femtosecond spectroscopies and calculations. J. Phys. Chem. B 2014, 118, 8756-8771. [CrossRef]

50. Moreno, J.; Gerecke, M.; Dobryakov, A.L.; Ioffe, I.N.; Granovsky, A.A.; Bleger, D.; Hecht, S.; Kovalenko, S.A. Two-photon-induced versus one-photon-induced isomerization dynamics of a bistable azobenzene derivative in solution. J. Phys. Chem. B 2015, 119, 12281-12288. [CrossRef]

51. Denk, W.; Strickler, J.; Webb, W. Two-photon laser scanning fluorescence microscopy. Science 1990, 248, 73-76. [CrossRef]

52. Benninger, R.K.P.; Piston, D.W. Two-photon excitation microscopy for the study of living cells and tissues. Curr. Protoc. Cell. Biol. 2013, 49, 4-11. [CrossRef]

53. Lee, G.H.; Moon, H.; Kim, H.; Lee, G.H.; Kwon, W.; Yoo, S.; Myung, D.; Yun, S.H.; Bao, Z.; Hahn, S.K. Multifunctional materials for implantable and wearable photonic healthcare devices. Nat. Rev. Mater. 2020, 1-7. [CrossRef]

54. Rost, B.R.; Schneider-Warme, F.; Schmitz, D.; Hegemann, P. Optogenetic tools for subcellular applications in neuroscience. Neuron 2017, 96, 572-603. [CrossRef] [PubMed]

55. Oron, D.; Papagiakoumou, E.; Anselmi, F.; Emiliani, V. Chapter 7-Two-Photon Optogenetics. Prog. Brain Res. 2012, 196, 119-143. [CrossRef]

56. Chaigneau, E.; Ronzitti, E.; Gajowa, M.A.; Soler-Llavina, G.J.; Tanese, D.; Brureau, A.Y.; Papagiakoumou, E.; Zeng, H.; Emiliani, V. Two-photon holographic stimulation of ReaChR. Front. Cell. Neurosci. 2016, 10. [CrossRef] [PubMed]

57. Yang, W.; Carrillo-Reid, L.; Bando, Y.; Peterka, D.S.; Yuste, R. Simultaneous two-photon imaging and two-photon optogenetics of cortical circuits in three dimensions. eLife 2018, 7, e32671. [CrossRef] [PubMed]

58. Yizhar, O.; Fenno, L.E.; Prigge, M.; Schneider, F.; Davidson, T.J.; O'shea, D.J.; Sohal, V.S.; Goshen, I.; Finkelstein, J.; Paz, J.T.; et al. Neocortical excitation/inhibition balance in information processing and social dysfunction. Nature 2011, 477, 171-178. [CrossRef] [PubMed]

59. Ronzitti, E.; Ventalon, C.; Canepari, M.; Forget, B.C.; Papagiakoumou, E.; Emiliani, V. Recent advances in patterned photostimulation for optogenetics. J. Opt. 2017, 19, 113001. [CrossRef]

60. Forli, A.; Vecchia, D.; Binini, N.; Succol, F.; Bovetti, S.; Moretti, C.; Nespoli, F.; Mahn, M.; Baker, C.A.; Bolton, M.M.; et al. Two-photon bidirectional control and imaging of neuronal excitability with high spatial resolution in vivo. Cell Rep. 2018, 22, 3087-3098. [CrossRef] [PubMed]

61. Mohanty, S.K.; Reinscheid, R.K.; Liu, X.; Okamura, N.; Krasieva, T.B.; Berns, M.W. In-depth activation of channelrhodopsin 2-sensitized excitable cells with high spatial resolution using two-photon excitation with a near-infrared laser microbeam. Biophys. J. 2008, 95, 3916-3926. [CrossRef]

62. Ellis-Davies, G.C.R. Two-photon uncaging of glutamate. Front. Synaptic Neurosci. 2019, 10. [CrossRef]

63. Volgraf, M.; Gorostiza, P.; Numano, R.; Kramer, R.H.; Isacoff, E.Y.; Trauner, D. Allosteric control of an ionotropic glutamate receptor with an optical switch. Nat. Chem. Biol. 2006, 2, 47-52. [CrossRef]

64. Levitz, J.; Pantoja, C.; Gaub, B.; Janovjak, H.; Reiner, A.; Hoagland, A.; Schoppik, D.; Kane, B.; Stawski, P.; Schier, A.F.; et al. Optical control of metabotropic glutamate receptors. Nat. Neurosci. 2013, 16, 507-516. [CrossRef] 
65. Izquierdo-Serra, M.; Gascón-Moya, M.; Hirtz, J.J.; Pittolo, S.; Poskanzer, K.E.; Ferrer, E.; Alibés, R.; Busqué, F.; Yuste, R.; Hernando, J.; et al. Two-photon neuronal and astrocytic stimulation with azobenzene-based photoswitches. J. Am. Chem. Soc. 2014, 136, 8693-8701. [CrossRef] [PubMed]

66. Gascón-Moya, M.; Pejoan, A.; Izquierdo-Serra, M.; Pittolo, S.; Cabré, G.; Hernando, J.; Alibés, R.; Gorostiza, P.; Busqué, F. An optimized glutamate receptor photoswitch with sensitized azobenzene isomerization. J. Org. Chem. 2015, 80, 9915-9925. [CrossRef] [PubMed]

67. Cabré, G.; Garrido-Charles, A.; Moreno, M.; Bosch, M.; Porta-de-la-Riva, M.; Krieg, M.; Gascón-Moya, M.; Camarero, N.; Gelabert, R.; Lluch, J.M.; et al. Rationally designed azobenzene photoswitches for efficient two-photon neuronal excitation. Nat. Commun. 2019, 10, 1-12. [CrossRef] [PubMed]

68. Rullo, A.; Reiner, A.; Reiter, A.; Trauner, D.; Isacoff, E.Y.; Woolley, G.A. Long wavelength optical control of glutamate receptor ion channels using a tetra-ortho-substituted azobenzene derivative. Chem. Commun. 2014, 50, 14613-14615. [CrossRef] [PubMed]

69. Laprell, L.; Repak, E.; Franckevicius, V.; Hartrampf, F.; Terhag, J.; Hollmann, M.; Sumser, M.; Rebola, N.; DiGregorio, D.A.; Trauner, D. Optical control of NMDA receptors with a diffusible photoswitch. Nat. Commun. 2015, 6. [CrossRef]

70. Riefolo, F.; Matera, C.; Garrido-Charles, A.; MJGomila, A.; Sortino, R.; Agnetta, L.; Claro, E.; Masgrau, R.; Holzgrabe, U.; Batlle, M.; et al. Optical control of cardiac function with a photoswitchable muscarinic agonist. J. Am. Chem. Soc. 2019, 141, 7628-7636. [CrossRef]

71. Pittolo, S.; Lee, H.; Lladó, A.; Tosi, S.; Bosch, M.; Bardia, L.; Gómez-Santacana, X.; Llebaria, A.; Soriano, E.; Colombelli, J.; et al. Reversible silencing of endogenous receptors in intact brain tissue using 2-photon pharmacology. Proc. Natl. Acad. Sci. USA 2019, 116, 13680-13689. [CrossRef]

72. Cabré, G.; Garrido-Charles, A.; González-Lafont, A.; Moormann, W.; Langbehn, D.; Egea, D.; Lluch, J.M.; Herges, R.; Alibés, R.; Busqué, F.; et al. Synthetic photoswitchable neurotransmitters based on bridged azobenzenes. Org. Lett. 2019, 21, 3780-3784. [CrossRef]

73. Passlick, S.; Richers, M.T.; Ellis-Davies, G.C.R. Thermodynamically stable, photoreversible pharmacology in neurons with one- and two-photon excitation. Angew. Chem. Int. Ed. 2018, 57, 12554-12557. [CrossRef]

74. Dong, M.; Babalhavaeji, A.; Samanta, S.; Beharry, A.A.; Woolley, G.A. Red-shifting azobenzene photoswitches for in vivo use. Acc. Chem. Res. 2015, 48, 2662-2670. [CrossRef]

75. Kienzler, M.A.; Reiner, A.; Trautman, E.; Yoo, S.; Trauner, D.; Isacoff, E.Y. A red-shifted, fast-relaxing azobenzene photoswitch for visible light control of an ionotropic glutamate receptor. J. Am. Chem. Soc. 2013, 135, 17683-17686. [CrossRef]

76. Hansen, M.J.; Lerch, M.M.; Szymanski, W.; Feringa, B.L. Direct and versatile synthesis of red-shifted azobenzenes. Angew. Chem. Int. Ed. 2016, 55, 13514-13518. [CrossRef]

77. Mourot, A.; Kienzler, M.A.; Banghart, M.R.; Fehrentz, T.; Huber, F.M.; Stein, M.; Kramer, R.H.; Trauner, D. Tuning photochromic ion channel blockers. ACS Chem. Neurosci. 2011, 2, 536-543. [CrossRef]

78. Carmi, I.; De Battista, M.; Maddalena, L.; Carroll, E.C.; Kienzler, M.A.; Berlin, S. Holographic two-photon activation for synthetic optogenetics. Nat. Protoc. 2018, 14, 864, under final review. [CrossRef]

79. Kim, H.M.; Cho, B.R. Two-photon probes for intracellular free metal ions, acidic vesicles, and lipid rafts in live tissues. Acc. Chem. Res. 2009, 42, 863-872. [CrossRef]

80. Dong, M.; Babalhavaeji, A.; Hansen, M.J.; Kálmán, L.; Woolley, G.A. Red, far-red, and near infrared photoswitches based on azonium ions. Chem. Commun. 2015, 51, 12981-12984. [CrossRef]

81. Sell, H.; Näther, C.; Herges, R. Amino-substituted diazocines as pincer-type photochromic switches. Beilstein J. Org. Chem. 2013, 9, 1-7. [CrossRef]

82. Thapaliya, E.R.; Zhao, J.; Ellis-Davies, G.C.R. Locked-azobenzene: testing the scope of a unique photoswitchable scaffold for cell physiology. ACS Chem. Neurosci. 2019, 10, 2481-2488. [CrossRef]

83. Hartrampf, F.W.W.; Barber, D.M.; Gottschling, K.; Leippe, P.; Hollmann, M.; Trauner, D. Development of a photoswitchable antagonist of NMDA receptors. Tetrahedron 2017, 73, 4905-4912. [CrossRef]

84. GÓmez-Santacana, X.; Pittolo, S.; Rovira, X.; Lopez, M.; Zussy, C.; Dalton, J.A.; Faucherre, A.; Jopling, C.; Pin, J.P.; Ciruela, F.; et al. Illuminating phenylazopyridines to photoswitch metabotropic glutamate receptors: from the flask to the animals. ACS Cent. Sci. 2017, 3, 81-91. [CrossRef]

85. Volgraf, M.; Gorostiza, P.; Szobota, S.; Helix, M.R.; Isacoff, E.Y.; Trauner, D. Reversibly caged glutamate: a photochromic agonist of ionotropic glutamate receptors. J. Am. Chem. Soc. 2007, 129, 260-261. [CrossRef] 
86. Jiang, C.; Li, H.T.; Zhou, Y.M.; Wang, X.; Wang, L.; Liu, Z.Q. Cardiac optogenetics: A novel approach to cardiovascular disease therapy. EP Eur. 2017, 20, 1741-1749. [CrossRef]

87. Gepstein, L.; Gruber, A. Optogenetic neuromodulation of the heart. J. Am. Coll. Cardiol. 2017, 70, $2791-2794$. [CrossRef]

88. Boyle, P.M.; Karathanos, T.V.; Trayanova, N.A. Cardiac optogenetics: 2018. JACC Clin. Electrophys. 2018, 4, 155-167. [CrossRef]

89. Tochitsky, I.; Kienzler, M.A.; Isacoff, E.; Kramer, R.H. Restoring vision to the blind with chemical photoswitches. Chem. Rev. 2018, 118, 10748-10773. [CrossRef]

90. Gaub, B.M.; Berry, M.H.; Visel, M.; Holt, A.; Isacoff, E.Y.; Flannery, J.G. Optogenetic retinal gene therapy with the light gated GPCR vertebrate rhodopsin. In Retinal Gene Therapy; Boon, C.J.F., Wijnholds, J., Eds.; Springer: New York, NY, USA, 2018; Volume 1715, pp. 177-189. [CrossRef]

91. Berry, M.H.; Holt, A.; Levitz, J.; Broichhagen, J.; Gaub, B.M.; Visel, M.; Stanley, C.; Aghi, K.; Kim, Y.J.; Cao, K.; et al. Restoration of patterned vision with an engineered photoactivatable G protein-coupled receptor. Nat. Commun. 2017, 8. [CrossRef]

92. Hüll, K.; Benster, T.; Manookin, M.B.; Trauner, D.; Van Gelder, R.N.; Laprell, L. Photopharmacologic vision restoration reduces pathological rhythmic field potentials in blind mouse retina. Sci. Rep. 2019, 9, 1-12. [CrossRef]

93. Samia, S.; Berlin, S. Bringing synthetic optogenetics to the clinic. J. Cell Signal. 2017, 2. [CrossRef]

94. Donthamsetti, P.C.; Winter, N.; Schönberger, M.; Levitz, J.; Stanley, C.; Javitch, J.A.; Isacoff, E.Y.; Trauner, D. Optical control of dopamine receptors using a photoswitchable tethered inverse agonist. J. Am. Chem. Soc. 2017, 139, 18522-18535. [CrossRef]

95. Borowiak, M.; Nahaboo, W.; Reynders, M.; Nekolla, K.; Jalinot, P.; Hasserodt, J.; Rehberg, M.; Delattre, M.; Zahler, S.; Vollmar, A.; et al. Photoswitchable inhibitors of microtubule dynamics optically control mitosis and cell death. Cell 2015, 162, 403-411. [CrossRef]

96. Cela, E.; Sjöström, P.J. Novel optogenetic approaches in epilepsy research. Front. Neurosci. $2019,13$. [CrossRef] [PubMed]

97. Gradinaru, V.; Zhang, F.; Ramakrishnan, C.; Mattis, J.; Prakash, R.; Diester, I.; Goshen, I.; Thompson, K.R.; Deisseroth, K. Molecular and cellular approaches for diversifying and extending optogenetics. Cell 2010, 141, 154-165. [CrossRef] [PubMed]

98. Fenno, L.; Yizhar, O.; Deisseroth, K. The development and application of optogenetics. Annu. Rev. Neurosci. 2011, 34, 389-412. [CrossRef] [PubMed]

99. Chen, I.W.; Ronzitti, E.; Lee, B.R.; Daigle, T.L.; Dalkara, D.; Zeng, H.; Emiliani, V.; Papagiakoumou, E. In vivo submillisecond two-photon optogenetics with temporally focused patterned light. J. Neurosci. 2019, 39, 3484-3497. [CrossRef]

(C) 2020 by the authors. Licensee MDPI, Basel, Switzerland. This article is an open access article distributed under the terms and conditions of the Creative Commons Attribution (CC BY) license (http://creativecommons.org/licenses/by/4.0/). 